\title{
New genetic findings in schizophrenia: is there still room for the dopamine hypothesis of schizophrenia?
}

\author{
Vanessa Nieratschker', Markus M. Nöthen ${ }^{2,3}$ and Marcella Rietschel ${ }^{1 *}$ \\ ' Division of Genetic Epidemiology in Psychiatry, Central Institute of Mental Health, Mannheim, Germany \\ 2 Department of Genomics, Life and Brain Center, University of Bonn, Bonn, Germany \\ 3 Institute of Human Genetics, University of Bonn, Bonn, Germany
}

\section{Edited by:}

Andreas Meyer-Lindenberg, Central Institute of Mental Health, Germany

\section{Reviewed by:}

Heike Tost, National Institute of Mental Health, USA

Joshua W. Buckholtz, Vanderbilt

University, USA

*Correspondence:

Marcella Rietschel, Division of Genetic Epidemiology in Psychiatry, Central

Institute of Mental Health, J5, 68159

Mannheim, Germany.

e-mail:marcella.rietsche/@

zi-mannheim.de
Schizophrenia is a highly heritable disorder, but the identification of specific genes has proven to be a difficult endeavor. Genes involved in the dopaminergic system are considered to be major candidates since the "dopamine hypothesis" of impairment in dopaminergic neurotransmission is one of the most widely accepted hypotheses of the etiology of schizophrenia. The overall findings from candidate studies do provide some support for the "dopamine hypothesis." However, results from the first systematic genome-wide association (GWA) studies have implicated variants within ZNF804A, NRGN, TCF4, and variants in the MHC region on chromosome 6p22.1. Although these genes may not immediately impact on dopaminergic neurotransmission, it remains possible that downstream impairments in dopaminergic function are caused. Furthermore, only a very small fraction of all truly associated genetic variants have been detected and many more associated variants will be identified in the future by GWA studies and alternative approaches. The results of these studies may allow a more comprehensive re-evaluation of the dopamine hypothesis.

Keywords: schizophrenia, heritability, genetic variants, linkage study, candidate gene, genome-wide association study CNV, dopamine hypothesis

\section{INTRODUCTION}

Schizophrenia is a severe psychiatric disorder with a lifetime prevalence that ranges between $0.5 \%$ and $1 \%$. Many aspects of its etiology and pathophysiology remain poorly understood despite extensive research. The considerable contribution made by genetic factors to the vulnerability to schizophrenia is, however, well recognized. The heritability of schizophrenia is around $80 \%$, and a first degree relative has a 5- to 10-fold increase in the risk of developing the disorder compared to the risk for the general population (Cardno and Gottesman, 2000; Sullivan et al., 2003). Beside genetic factors, environmental factors are also involved in the etiology of the disease. We will briefly review the formal genetic evidence available for schizophrenia and then provide an overview of the most significant molecular genetic findings, with an emphasis on how the latest findings obtained using array-based technologies have challenged our understanding of the genetic architecture underlying schizophrenia. We will also discuss how these new approaches may assist in comprehensively re-examining pathophysiological hypotheses such as the dopamine hypothesis of schizophrenia.

\section{FORMAL GENETIC STUDIES}

A large number of studies have demonstrated that schizophrenia runs in families and that the average life time risk for first degree relatives is $10 \%$ (compared to a life time prevalence of approximately $1 \%$ in the general population). Certain features show particularly high familiality, such as age and mode of onset, the course of the disorder, the degree of impairment during the disorder, premorbid functioning, psychomotor deficiency, disorganization, and manic features (Wickham et al., 2001, 2002). Family studies are able to demonstrate that a disorder, or a specific symptom of a disorder, runs in families. However, they can not distinguish whether the familial aggregation is due to environmental or genetic factors since family members share some of their genes as well as many elements of their environment. In order to separate environmental from genetic factors, twin and adoption studies are conducted. Twin studies compare the rate of concordance between monozygotic (MZ) twins and dizygotic (DZ) twins. On average, DZ twins share $50 \%$ of their genes, as is the case with other non-twin siblings. Both kind of twins normally share a large fraction of their environment, and typically more so than other siblings or relatives. If there is a genetic contribution, the concordance rate for a genetically affected disorder should be higher for MZ than for DZ twins. Almost all of the twin studies of schizophrenia conducted to date have shown a higher concordance rate in MZ twins (40-65\%) than in DZ twins (0-28\%) which indicates a clear genetic component to its etiology (Cardno et al., 1999; Cardno and Gottesman, 2000; Kringlen, 2000). Further evidence that schizophrenia is genetically transmitted has been obtained from adoption studies which have shown that the biological relatives of schizophrenia patients have a higher risk of developing the disorder (Lowing et al., 1983; Kendler and Gruenberg, 1984; Kety, 1987; Kendler et al., 1994; Kety et al., 1994; Tienari et al., 2000, 2003). However, adoption studies have also demonstrated that the adopted-away children of mothers with schizophrenia only have a higher risk of developing the disorder when other psychological abnormalities are present in the adoptive family (Tienari et al., 2000, 2003; Wynne et al., 2006). Children of healthy biological parents who are adopted by a family with parents affected by schizophrenia do not themselves 
have an increased risk of developing the disorder. These studies demonstrate the influence of genetic factors on the vulnerability to schizophrenia, but they also clearly demonstrate that environmental factors contribute substantially to the manifestation of the disorder. Individuals with schizophrenia often suffer from other co-morbid psychiatric conditions. Epidemiological studies have revealed an increased prevalence of depression, anxiety disorders, and substance abuse disorders in schizophrenia patients compared to the general population (for review see Buckley et al., 2009). There is also substantial evidence for an overlap between schizophrenia and bipolar disorder. For example, relatives of patients with bipolar disorder have an increased risk of developing schizophrenia and vice versa (Valles et al., 2000; Cardno et al., 2002; Maier et al., 2002; Laursen et al., 2009; Lichtenstein et al., 2009; Van Snellenberg and de Candia, 2009).

\section{MOLECULAR GENETIC STUDIES}

Linkage and association studies have been conducted to attempt to identify the genetic factors on a molecular level (Figure 1). In association studies there are two complementary approaches. The first approach is based on candidate genes that are either selected because the chromosomal region harboring the gene has been previously identified, e.g. in systematic linkage analyses (positional candidates), or because the selected gene fits into a specific a priori hypothesis regarding the underlying pathophysiology (functional candidates). The second approach does not depend on any pre-existing hypothesis or knowledge of a specific gene or gene region. Instead, the whole genome is investigated systematically for risk variants (genome-wide association study; GWA study). Until recently, a systematic, genome-wide screen was only possible in linkage studies, which search for a correlation between genetic markers and affection status in families with multiple affected members and which require the genotyping of only a few hundred genetic markers. In the past, association studies focused exclusively on candidate genes, but advances in genotyping technology and progress in understanding the genetic variability of the human genome now permit use of the systematic, genome-wide screen.

The various approaches used to investigate schizophrenia and their results will now be presented and discussed.

\section{LINKAGE STUDIES}

Linkage studies aim to discover genomic regions that are co-transmitted with the disorder in families with several affected members. Systematic, family based genome-wide linkage studies are extremely successful in detecting rare variants with strong effects on the etiology of the disorder. This approach has been applied effectively to discover genetic factors underlying monogenic Mendelian diseases such as Huntington's disease (Gusella et al., 1983). However, this method is less effective in discovering genes that contribute only moderately to the etiology of a complex, heterogeneous disorder. In complex disorders, the presence of a specific vulnerability gene may not even be necessary. In their landmark paper, Risch and Merikangas (1996) calculated the number of families (affected sib pairs) required to demonstrate linkage. If gene effects are small, a dramatic reduction in the excess allele sharing between affected sibs will result, and very large samples will be necessary to demonstrate linkage. Meta-analyses of linkage scans attempt to overcome limitations in statistical power by combining data from various independent studies. These analyses have provided evidence for loci on 2q, 5q, 8p, 13q, and 22q (Badner and Gershon, 2002; Lewis et al., 2003; Ng et al., 2009).

Interestingly, various genomic loci that are shared between schizophrenia and bipolar affective disorder have been reported. The best supported regions are $13 \mathrm{q}$ and $22 \mathrm{q}$ (Badner and Gershon, 2002).

\section{ASSOCIATION STUDIES - CANDIDATE GENES}

Association studies are usually conducted using a case-control design, and they are performed in order to detect alleles that have an altered frequency in unrelated patients as compared to unrelated control subjects. Association studies have a greater power than linkage studies to detect common risk alleles with small effects (Risch and Merikangas, 1996). In order to conduct a systematic association screen covering the whole genome, it is necessary to genotype hundreds of thousands of polymorphisms. Until recently, systematic association approaches were not possible due to limitations in genotyping technology and limited knowledge of the variability of the human genome, and previous association studies therefore focused exclusively on candidate genes.

The functional candidate gene approach is restricted by our limited knowledge of the biological pathways underlying the etiology of schizophrenia. However, one of the most common and widely accepted hypotheses is the "dopamine hypothesis." This proposes that a dysfunction in the dopaminergic neurotransmitter system, which leads to a reduced dopamine concentration in cortical regions and to an excess of dopamine in striatal areas of the brain, is involved in the pathogenesis of schizophrenia (for review see Howes and Kapur, 2009). Genes involved in dopaminergic neurotransmission such as the dopamine transporter 1 (DAT1), dopamine receptor 1-5 (DRD1-5), and catechol-O-methyltransferase (COMT) are therefore major candidates for genetic association studies. Variants in these genes have been found to be associated with schizophrenia in independent studies (e.g. Sivagnanasundaram et al., 2000; Shifman et al., 2002; Jönsson et al., 2003; Staddon et al., 2005; Shi et al., 2008; Talkowski et al., 2008), although none of these findings have been unequivocally accepted since there has been insufficient evidence across studies (e.g. Jönsson et al., 2001, 2004; Georgieva et al., 2002; Serretti et al., 2004; Okochi et al., 2009).

To facilitate the interpretation of the many association findings in schizophrenia, a regularly updated online database of all published genetic association studies for schizophrenia ("SzGene") has been created (http://www.schizophreniaforum.org/res/sczgene/ default.asp). The group of researchers that set up the database has also performed meta-analyses in at least four independent casecontrol samples for all polymorphisms with available genotype data (Allen et al., 2008). Across 118 meta-analyses, a total of 24 genetic variants in 16 different genes (APOE, COMT, DAO, DRD1, DRD2, DRD4, DTNBP1, GABRB2, GRIN2B, HP, IL1B, MTHFR, PLXNA2, SLC6A4, TP53, and TPH1) showed nominally significant effects with average summary odds ratios of approximately 1.23. Using recently proposed criteria for the assessment of cumulative evidence in genetic association studies, the authors characterized four of the significant results, including DRD1, as showing "strong" epidemiological credibility. 


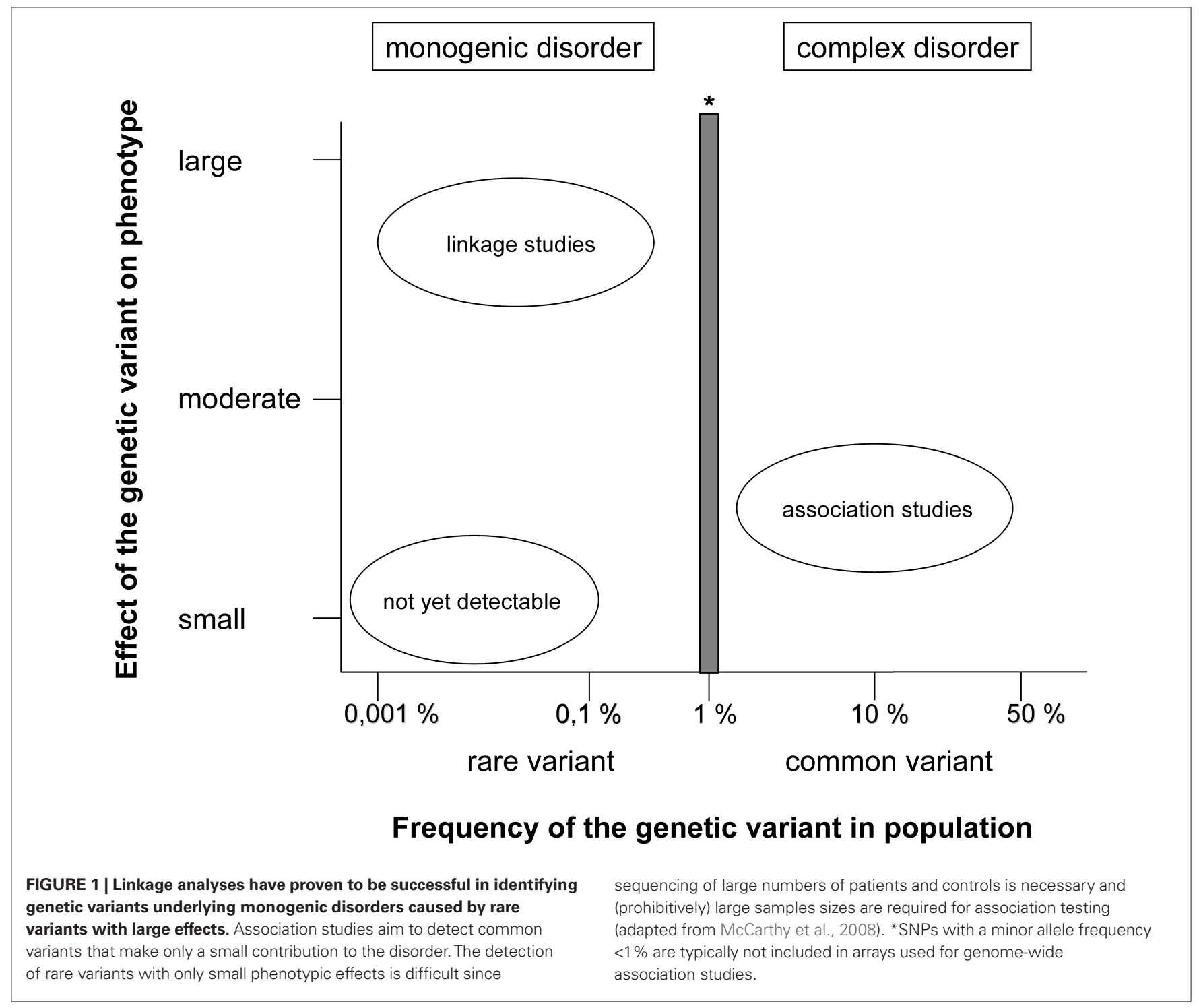

Candidate gene based association studies have also identified susceptibility genes that may increase the risk for both schizophrenia and bipolar disorder. These genes include DISC1, DTNBP1, COMT, NRG1, and DAOA (G72/G30) (for review see Craddock et al., 2005, 2006; Owen et al., 2007). The strongest support for a transcategorical overlap has been reported for G72/G30, a gene in the 13q candidate region (Chumakov et al., 2002; Schumacher et al., 2004; Jamra et al., 2006). For some of the loci and genes described above, detailed analysis has shown that the association is due to subgroups of patients who suffer from symptoms that are common to both disorders. An association of G72/G30 with schizophrenia and bipolar disorder, for example, was found to be mediated mainly by bipolar patients with psychotic symptoms (Schulze et al., 2005).

\section{GENOME-WIDE ASSOCIATION STUDIES}

It is now possible to perform association studies on a genomewide scale [up to 1,000,000 single nucleotide polymorphisms (SNPs)] as a result of improved understanding of the variability of the human genome (e.g. HapMap Project, International HapMap Consortium, 2003) and advances in array technology for multiplex genotyping. GWA studies identify frequent SNPs that are associated with common complex disorders. Association between diseases and SNPs with low minor allele frequencies usually remain undetected since these SNPs are not well represented on currently available arrays. A major difficulty in evaluating the results of GWA studies is the issue of multiple testing. The testing of up to $1,000,000$ SNPs for their association with a disease leads to many false positive findings, and it is necessary to correct for multiple testing to achieve the level of genome-wide significance. The level of genome-wide significance depends on the number of SNPs analyzed, and the threshold is approximately $5 \times 10^{-8}$ for the GWA-chips that are used currently $(660,000-1,000,000$ SNPs) (Dudbridge and Gusnanto, 2008; Hoggart et al., 2008; Pe'er et al., 2008). This correction method is very conservative since the association findings of each SNP are considered to be independent, and the haplotype structure of the genome is not taken into account. Although conservative correction for multiple 
testing reduces the risk of false positive findings, it hampers the detection of true association signals with small effects on the risk for schizophrenia.

Successful GWA studies have been conducted for several common, complex diseases including diabetes type 2, myocardial infarction, breast cancer, and Crohn's disease (for all published studies see http:// www.genome.gov/gwastudies/). The first GWA studies for schizophrenia have now been reported (Mah et al., 2006; Lencz et al., 2007; O’Donovan et al., 2008; Shifman et al., 2008; Sullivan et al., 2008; Kirov et al., 2009b; Need et al., 2009; International Schizophrenia Consortium, 2009; Shi et al., 2009; Stefansson et al., 2009). The results of these studies are shown in Table $\mathbf{1}$ and are summarized below.

Three of these studies used pooled DNA samples (Mah et al., 2006; Shifman et al., 2008; Kirov et al., 2009b). This cost-effective method is effective in identifying disease genes (e.g. Liu et al., 2005; Johnson et al., 2006), although it is less sensitive than individual genotyping due to measurement errors in DNA quantification and results in reduced power. A further limitation of this method is that the evaluation of data is limited to the study of (estimated) allele frequencies at the level of individual SNPs. It cannot detect effects of haplotypes, interaction between SNPs, and effects of genotypes that do not show up in allele frequency differences. The best supported variants in these studies did not achieve genome-wide significance (Mah et al., 2006; Shifman et al., 2008; Kirov et al., 2009b) (see Table 1).

The first GWA study of schizophrenia based on individual genotyping used a sample of only 178 cases and 144 controls (Lencz et al., 2007). The best hit was a variant in the vicinity of the colony-stimulating factor-2 receptor alpha (CSF2RA) gene, but this did not reach genome-wide significance (Lencz et al., 2007). The second GWA study based on individual genotyping included a larger sample of 738 patients and 733 controls. This study also failed to find any genome-wide significant association, although a few signals coincided with genomic regions implicated previously in schizophrenia (Sullivan et al., 2008). O’Donovan et al. (2008) performed their initial GWA study using a moderately sized sample of 479 patients. However, they enhanced the statistical power by conducting a follow-up study of 12 markers associated with a $p$-value $\leq 10^{-5}$ in a much larger sample. Three of these 12 markers showed strong evidence for replication $\left(p \leq 5 \times 10^{-4}\right)$. However, their best supported variant failed to achieve the level of genomewide significance (Table 1). The highest ranking SNP from this study is located in an intron of the zinc finger protein $804 \mathrm{~A}$ gene (ZNF804A), a putative transcription factor. This had been neither investigated nor implicated in the risk for schizophrenia. The case sample was then extended to include bipolar patients and the $p$ value for the total sample of major psychosis patients surpassed the level of genome-wide significance $\left(p=9 \times 10^{-9}\right)$. The International Schizophrenia Consortium (2009) has subsequently replicated the association between ZNF804A and schizophrenia, and ZNF804A is therefore a promising true susceptibility gene for schizophrenia. Need et al. (2009) performed an initial GWA study of 871 schizophrenia patients and 863 controls and then followed up their best hits in a replication sample of 1460 cases and 12,995 controls. However, they failed to detect any association signal that could withstand correction for multiple testing.
Three recent multicenter studies may have heralded a breakthrough in GWA studies of schizophrenia. None of the initial findings from these three studies surpassed the level of genomewide significance. However, a meta-analysis of the best hits on European-ancestry data from these three studies and the inbuild replication study by Stefansson et al. identified a cluster of genomewide significant SNPs in substantial LD in the MHC region on chromosome 6p22.1 (International Schizophrenia Consortium, 2009; Shi et al., 2009; Stefansson et al., 2009). These results may implicate the immunological system in the pathogenesis of schizophrenia. Stefansson et al. (2009) also found that a variant upstream of neurogranin $\left(N R G N ; p=2.4 \times 10^{-9}\right)$ and a SNP in transcription factor $4\left(T C F 4 ; p=4.1 \times 10^{-9}\right)$ achieved genome-wide significance. These findings demonstrate that the use of large samples can overcome the limitations in the power of GWA studies to detect common risk variants for complex psychiatric disorders.

The International Schizophrenia Consortium study showed that the SNPs which failed to reach genome-wide significance included some true genetic risk factors. Firstly, variations across nominally associated loci were summarized into quantitative scores in a discovery case-control study. Aggregate risk scores for individuals in independent case-control samples were then calculated. Score alleles designated in the discovery sample were significantly enriched among replication cases. The International Schizophrenia Consortium also showed that the same "set of score alleles" distinguished bipolar cases from controls, thus providing support for the hypothesis that there is a genetic overlap between schizophrenia and bipolar disorder. Although these SNPs explained only approximately $3 \%$ of the variance in schizophrenia risk, this can be regarded as the first molecular genetic evidence in support of the theory of the polygenic inheritance of schizophrenia (International Schizophrenia Consortium, 2009).

Can the GWA data be used to re-evaluate major pathophysiological hypotheses of schizophrenia such as the dopamine hypothesis? Data obtained from GWA studies offer great opportunities for addressing such key questions. Firstly, to test a certain pathophysiological hypothesis, the relevant data can be extracted (e.g. SNP data from genes involved in dopaminergic neurotransmission) and specifically tested for association with the diagnosis of schizophrenia. The number of statistical tests can be greatly reduced in comparison to genome-wide analyses, reducing the necessary correction factor applied for multiple testing, and this approach thus enables the identification of smaller genetic effects. Secondly, it is possible that dopaminergic dysfunction may emerge as a downstream consequence of genetic variation in the (non-canonical) candidate genes identified in GWA studies, thereby reconciling the seemingly inconsistent findings that genetic associations with dopaminergic pathway genes are rather weak, whereas "higher level" (e.g. neuroimaging) findings linking dopamine to psychosis are robust.

\section{SMALL CHROMOSOMAL ABERRATIONS}

Small chromosomal aberrations (copy number variations, genomic imbalances) may confer a risk for schizophrenia, as with the 22q11.2 Deletion Syndrome (22q11.2 DS). This common microdeletion syndrome presents with congenital and late-onset features including a high risk for neuropsychiatric diseases (up to 
Table 1 | Published genome-wide association studies for schizophrenia: all schizophrenia GWA studies published to date are shown. The number of variants investigated, the best associated SNP(s) found and the gene(s) containing that SNP(s), the corresponding $p$-value(s) and the number of cases and controls in the discovery and the replication/meta-analysis sample are all given.

\begin{tabular}{|c|c|c|c|c|c|c|c|}
\hline Mah et al. (2006) & $\sim 25,000$ & rs752016 & plexin A2 (PLXNA2) & 0.006 & $\begin{array}{l}320 \text { cases, } 325 \\
\text { controls }\end{array}$ & 0.035 & $\begin{array}{l}200 \text { cases, } 230 \\
\text { controls (EA) }\end{array}$ \\
\hline Lencz et al. (2007) & $\sim 500,000$ & rs4129148 & $\begin{array}{l}\text { colony stimulating } \\
\text { factor, receptor } 2 \\
\text { alpha (CSF2RA) }\end{array}$ & $3.7 \times 10^{-7}$ & $\begin{array}{l}178 \text { cases, } 144 \\
\text { controls }\end{array}$ & & \\
\hline $\begin{array}{l}\text { Sullivan et al. } \\
(2008)\end{array}$ & $\sim 500,000$ & rs4846033 & & $4.4 \times 10^{-6}$ & $\begin{array}{l}738 \text { cases, } 733 \\
\text { controls }\end{array}$ & & \\
\hline $\begin{array}{l}\text { O'Donovan et al. } \\
(2008)\end{array}$ & $\sim 500,000$ & rs1344706 & $\begin{array}{l}\text { zink finger protein } \\
804 A \text { (ZNF804A) }\end{array}$ & $1.8 \times 10^{-6}$ & $\begin{array}{l}479 \text { cases, } 2937 \\
\text { controls }\end{array}$ & $1.6 \times 10^{-7}$ & $\begin{array}{l}7308 \text { cases, } \\
12834 \text { controls }\end{array}$ \\
\hline Need et al. (2009) & $\sim 550,000$ & rs2135551 & $\begin{array}{l}\text { ADAMTS like } 3 \\
\text { (ADAMTSL3) }\end{array}$ & $1.3 \times 10^{-6}$ & $\begin{array}{l}871 \text { cases, } 863 \\
\text { controls }\end{array}$ & & $\begin{array}{l}1460 \text { cases, } \\
12995 \text { controls }\end{array}$ \\
\hline \multirow[t]{2}{*}{ Shi et al. (2009) } & $\sim 600,000$ & rs13025591 & $\begin{array}{l}\text { ArfGAP with GTPase } \\
\text { domain, ankyrin } \\
\text { repeat and PH } \\
\text { domain } 1 \text { (AGAP1) }\end{array}$ & $\begin{array}{l}4.6 \times 10^{-7} \\
\text { (in EA) }\end{array}$ & $\begin{array}{l}2681 \text { cases, } 2653 \\
\text { controls (EA); } \\
1286 \text { cases, } 973 \\
\text { controls (AA) }\end{array}$ & & \\
\hline & & rs1851196 & $\begin{array}{l}\text { v-erb-a erythroblastic } \\
\text { leukemia viral } \\
\text { oncogene homolog } 4 \\
\text { (avian) (ERBB4) }\end{array}$ & $\begin{array}{l}2.1 \times 10^{-6} \\
(\text { in } A A)\end{array}$ & & & \\
\hline \multirow{2}{*}{$\begin{array}{l}\text { International } \\
\text { Schizophrenia } \\
\text { Consortium (2009) }\end{array}$} & $\sim 1,000,000$ & rs5761163 & $\begin{array}{l}\text { myosin XVIIIB } \\
(\text { MYO18B) }\end{array}$ & $3.4 \times 10^{-7}$ & $\begin{array}{l}3322 \text { cases, } \\
3587 \text { controls }\end{array}$ & & $\begin{array}{l}8008 \text { cases, } \\
19077 \text { controls }\end{array}$ \\
\hline & & rs13194053 & $\begin{array}{l}\text { major } \\
\text { histocompatibility } \\
\text { complex }(\mathrm{MHC})\end{array}$ & & & $9.5 \times 10^{-9}$ & \\
\hline \multirow[t]{3}{*}{$\begin{array}{l}\text { Stefansson et al. } \\
\text { (2009) }\end{array}$} & $\sim 300,000$ & 5 variants & $\begin{array}{l}\text { major } \\
\text { histocompatibility } \\
\text { complex }(\mathrm{MHC})\end{array}$ & & $\begin{array}{l}2663 \text { cases, } \\
13498 \text { controls }\end{array}$ & $\begin{array}{l}1.1 \times 10^{-9} \\
1.4 \times 10^{-12}\end{array}$ & $\begin{array}{l}12945 \text { cases, } \\
34591 \text { controls }\end{array}$ \\
\hline & & rs12807809 & neurogranin (NRGM) & & & $2.4 \times 10^{-9}$ & \\
\hline & & rs9960767 & $\begin{array}{l}\text { transcription factor } 4 \\
\text { (TCF4) }\end{array}$ & & & $4.1 \times 10^{-9}$ & \\
\hline
\end{tabular}


a 25\% risk for schizophrenia) (Karayiorgou et al., 1995; Bassett et al., 2005). Attempts to correlate the occurrence of schizophrenia with the extent of the deletion in these patients have been unsuccessful. An increase in the susceptibility to schizophrenia may involve the altered expression of several genes within the 22q11.2 region (Meechan et al., 2007; Sivagnanasundaram et al., 2007), and this may explain the lack of replicable results from studies aiming to implicate individual genes from the deletion region as general susceptibility genes for schizophrenia (Glaser et al., 2006).

The availability of new technologies such as comparative genomic hybridization and SNP-arrays in GWA studies has enabled the identification of small chromosomal aberrations on a genome-wide scale. The first such studies of schizophrenia found increased overall rates of aberrations (Walsh et al., 2008; Xu et al., 2008). More recent studies have implicated specific chromosomal regions. These include microdeletions in chromosomal regions $1 \mathrm{q} 21.1,2 \mathrm{p} 16.3,15 \mathrm{q} 11.2$, and 15q13.3, as well as microduplication in chromosomal region 15q13.1 (International Schizophrenia Consortium, 2008; Kirov et al., 2009a; Need et al., 2009; Rujescu et al., 2009). All of these variants are found more frequently among patients than among controls, although the frequency of each individual variant in schizophrenia patients is low $(<1 \%)$. Further studies are necessary to determine the penetrance, the mutation rate, and the full phenotypic spectrum associated with these aberrations. Some variants appear to be more frequent in patients with other central nervous system phenotypes such as mental disability, epilepsy, and autism (Mefford et al., 2008; Ben-Shachar et al., 2009; Helbig et al., 2009; Miller et al., 2009). This suggests that these disorders may have common etiological factors.

As illustrated by the difficulties encountered in identifying the causative gene/s in the 22 q11.2 region, identification of the causative genes in the newly implicated chromosomal regions may not be straightforward. Perhaps the most promising gene implicated to date is the neurexin 1 gene (NRXNA1), which is located in the deleted region on chromosome 2p16. Smaller chromosomal aberrations that specifically affect this gene have already been identified (Kirov et al., 2008; Vrijenhoek et al., 2008; Rujescu et al., 2009).

\section{OUTLOOK}

It is well established that schizophrenia is a highly heritable, complex disease. Our understanding of its underlying pathophysiology, however, remains limited. Until recently, the systematic genome-wide search for genetic risk factors was only possible through linkage approaches, with the limitation of insufficient power to detect genes with small effects. GWA studies overcome this limitation, and the first GWA studies of schizophrenia have now been published with many more being expected to follow. In addition, large meta-analyses to increase the statistical power are currently under way. The identification of risk genes will provide a vast array of possibilities to be pursued in further research into the underlying causes of schizophrenia. One of the variants highlighted in a GWA study, the SNP in the ZNF804A gene, for example, was subsequently investigated using a functional neuroimaging approach. Esslinger et al. (2009) were able to show that risk allele carriers have reduced connectivity in the dorsolateral prefrontal cortex (DLPFC), and an increased connectivity between the DLPFC and the hippocampus formation, as well as between the amygdala and other brain regions. Disturbed interactions between different brain regions have previously been described as endophenotypes underlying schizophrenia (e.g. Meyer-Lindenberg et al., 2005; Stephan et al., 2006). This demonstrates that studies that combine genetic data and intermediate phenotype findings have enormous potential for increasing our understanding of the impact of specific functions of the human brain on the development of disease. Besides functional neuroimaging studies, other promising intermediate phenotypes include structural neuroimaging, gene expression in the post-mortem brain, cognitive function and behavioral and physiological measures (for review see Bray, 2008; Gallinat et al., 2008; Prasad and Keshavan, 2008; Dean et al., 2009).

Another approach that can be applied following the initial identification of a susceptibility gene is reverse phenotyping (Schulze et al., 2005; Rietschel et al., 2008). Reverse phenotyping systematically identifies the phenotypic features that show the strongest association with the genetic risk factor identified in genetic studies. It is of great interest to understand the spectrum (or cluster) of phenotypes that are associated with a specific genetic risk factor since this means that they are causally linked and that shared biological pathways contribute to their development. In the future, the genetic data may also be used to improve the definition of the phenotype in the clinical setting.

The GWA data will be an extremely valuable resource for a variety of future studies. These will include analytical approaches such as gene-based approaches, pathway analysis, and convergent functional genomics which aim to detect additional susceptibility genes with greater power (Le-Niculescu et al., 2009; Treutlein et al., 2009). In particular, pathway-based approaches will allow the systematic re-evaluation of major pathophysiological hypotheses of schizophrenia such as the dopamine hypothesis.

The GWA studies have taught us that common susceptibility variants confer only a small individual risk and are likely to account for only a limited proportion (International Schizophrenia Consortium, 2009) of the overall genetic risk factors underlying schizophrenia. Some of the rare CNVs described recently contribute more strongly to individual risk than the common SNPs that have been found to be associated with schizophrenia. At present, it is only possible to detect novel CNVs spanning at least several thousand base pairs using DNA-microarray-chips. It will be necessary to apply other approaches such as the re-sequencing of candidate regions or whole genome sequencing to detect $\mathrm{CNV}$ s involving fewer base pairs (or even all rare single nucleotide substitutions). If the genetic effect of such variants is not very strong, however, very large sample sizes will be required to ensure sufficient statistical power to detect association with disease.

In the light of recent findings, the genetic approach can finally be considered to have started to deliver what it has promised for a number of years. The identification of genes associated with schizophrenia is already beginning to substantially increase our knowledge of its underlying pathophysiology. Is there still room for the dopamine hypothesis of schizophrenia when recent genetic findings are taken into consideration? The performance of GWA 
studies has led to the identification of previously unknown and largely unexpected genes. It is possible that genetic variants in risk genes identified in GWA studies lead to downstream impairments in dopaminergic function. It is also important to remember that only a very small fraction of all truly associated variants have been detected and that many more associated variants will be identified in the future. These will include already known variants

\section{REFERENCES}

Allen, N. C., Bagade, S., McQueen, M. B., Ioannidis, J. P., Kavvoura, F. K., Khoury, M. J., Tanzi, R. E., and Bertram, L. (2008). Systematic metaanalyses and field synopsis of genetic association studies in schizophrenia: the SzGene database. Nat. Genet. 40, 827-834.

Badner, J. A., and Gershon, E. S. (2002). Meta-analysis of whole-genome linkage scans of bipolar disorder and schizophrenia. Mol. Psychiatry 7, 405-411.

Bassett, A. S., Chow, E. W., Husted, J. Weksberg, R., Caluseriu, O., Webb, G. D., and Gatzoulis, M. A. (2005). Clinical features of 78 adults with 22q11 Deletion Syndrome. Am. J. Med. Genet. A 138, 307-313.

Ben-Shachar, S., Lanpher, B., German, J.R., Qasaymeh, M., Potocki, L., Nagamani, S. C., Franco, L. M., Malphrus, A., Bottenfield, G.W., Spence, J.E., Amato, S., Rousseau, J.A., Moghaddam, B., Skinner, C., Skinner, S.A., Bernes, S., Armstrong, N., Shinawi, M., Stankiewicz, P., Patel, A., Cheung, S. W., Lupski, J. R., Beaudet, A. L., and Sahoo, T. (2009). Microdeletion 15q13.3: a locus with incomplete penetrance for autism, mental retardation, and psychiatric disorders. J. Med. Genet. 46, 382-388.

Bray, N. J. (2008). Gene expression in the etiology of schizophrenia. Schizophr. Bull. 34, 412-418.

Buckley, P. F., Miller, B. J., Lehrer, D. S., and Castle, D. J. (2009). Psychiatric comorbidities and schizophrenia. Schizophr. Bull. 35, 383-402.

Cardno, A. G., and Gottesman, I. I. (2000). Twin studies of schizophrenia: from bow-and-arrow concordances to star wars $\mathrm{Mx}$ and functional genomics. Am. J. Med. Genet. 97, 12-17.

Cardno, A. G., Marshall, E. J., Coid, B., Macdonald, A. M., Ribchester, T. R. Davies, N. J., Venturi, P., Jones, L. A., Lewis, S. W., Sham, P. C., Gottesman, II, Farmer, A. E., McGuffin, P., Reveley, A. M., and Murray, R. M. (1999). Heritability estimates for psychotic disorders: the Maudsley twin psychosis series. Arch. Gen. Psychiatry $56,162-168$.

Cardno, A. G., Rijsdijk, F. V., Sham, P. C., Murray, R.M., and McGuffin,P.(2002).
A twin study of genetic relationships between psychotic symptoms. Am. J. Psychiatry 159, 539-545.

Chumakov, I., Blumenfeld, M. Guerassimenko, O., Cavarec, L., Palicio, M., Abderrahim, H., Bougueleret, L., Barry, C., Tanaka, H., La Rosa, P., Puech, A., Tahri, N., Cohen-Akenine A., Delabrosse, S., Lissarrague, S. Picard, F. P., Maurice, K., Essioux, L. Millasseau, P., Grel, P., Debailleul, V., Simon, A. M., Caterina, D., Dufaure, I., Malekzadeh, K., Belova, M., Luan, J. J., Bouillot, M., Sambucy, J. L., Primas, G., Saumier, M., Boubkiri, N., MartinSaumier, S., Nasroune, M., Peixoto, H., Delaye, A., Pinchot, V., Bastucci, M., Guillou, S., Chevillon, M., SainzFuertes, R., Meguenni, S.,Aurich-Costa, J., Cherif, D., Gimalac, A., Van Duijn, C., Gauvreau, D., Ouellette, G., Fortier, I., Raelson, J., Sherbatich, T., Riazanskaia, N., Rogaev, E., Raeymaekers, P., Aerssens, J., Konings, F., Luyten, W., E., Weinberger, D. R., Cohen, N., and Cohen, D. (2002). Genetic and physiological data implicating the new human gene $\mathrm{G} 72$ and the gene for D-amino acid oxidase in schizophrenia. Proc. Natl. Acad. Sci. U.S.A. 99, 13675-13680. Owen, M. J. (2005). The genetics of schizophrenia and bipolar disorder: dissecting psychosis. J. Med. Genet. 42, 193-204.

Craddock, N., O'Donovan, M. C., and Owen, M. J. (2006). Genes for schizophrenia and bipolar disorder? Implications for psychiatric nosology. Schizophr. Bull. 32, 9-16.

Dean, B., Boer, S., Gibbons, A., Money, T., and Scarr, E. (2009). Recent advances in postmortem pathology and neurochemistry in schizophrenia. Curr Opin. Psychiatry 22, 154-160.

Dudbridge, F., and Gusnanto, A. (2008). Estimation of significance thresholds for genomewide association scans. Genet. Epidemiol. 32, 227-234.

Esslinger, C., Walter, H., Kirsch, P., Erk, S., Schnell, K., Arnold, C., Haddad, L., Mier, D., von Boberfeld, C. O., Raab, K., Witt, S. H., Rietschel, M., Cichon, S., and Meyer-Lindenberg, A. (2009). Neural mechanisms of a genome-wide supported psychosis variant. Science 324, 605. Macciardi, F., Sham, P. C., Straub, R.

Craddock, N., O'Donovan, M. C., and

which do not currently surpass the level of genome-wide significance in GWA studies; the identification of other variants will require additional experimental approaches (see above). It is possible that these as yet undetected genes encode proteins that participate directly in dopaminergic neurotransmission such as dopamine transporters, dopamine receptors, and synthetic and catabolic enzymes.

Gallinat, J., Bauer, M., and Heinz, A. (2008). Genes and neuroimaging. advances in psychiatric research. Neurodegener. Dis. 5, 277-285.

Georgieva, L., Dimitrova, A., Nikolov, I., Koleva, S., Tsvetkova, R., Owen, M. J., Toncheva, D., and Kirov, G. (2002). Dopamine transporter gene (DAT1) VNTR polymorphism in major psychiatric disorders: family-based association study in the Bulgarian population. Acta Psychiatr. Scand. 105, 396-399.

Glaser, B., Moskvina, V., Kirov, G. Murphy, K. C., Williams, H., Williams, N., Owen, M. J., and O'Donovan, M. C. (2006). Analysis of ProDH, COMT and ZDHHC8 risk variants does not support individual or interactive effects on schizophrenia susceptibility. Schizophr. Res. 87, 21-27.

Gusella, J. F., Wexler, N. S., Conneally, P. M., Naylor, S. L., Anderson, M. A. Tanzi, R. E., Watkins, P. C., Ottina, K., Wallace, M. R., Sakaguchi, A. Y., Young, A. B., Shoulson, I., Bonilla, E. and Martin, J. B.(1983). A polymorphic DNA marker genetically linked to Huntington's disease. Nature 306 234-238.

Helbig, I., Mefford, H. C., Sharp, A. J., Guipponi, M., Fichera, M., Franke, A., Muhle, H., de Kovel, C., Baker, C. von Spiczak, S., Kron, K. L., Steinich, I., Kleefuss-Lie, A. A., Leu, C., Gaus, V., Schmitz, B., Klein, K. M., Reif, P. S., Rosenow, F., Weber, Y., Lerche, H. Zimprich, F.,Urak,L., Fuchs, K., Feucht, M., Genton, P., Thomas, P., Visscher, F. de Haan, G. J., Moller, R. S., Hjalgrim, H., Luciano, D., Wittig, M., Nothnagel, M., Elger, C. E., Nurnberg, P., Romano, C., Malafosse, A., Koeleman, B. P., Lindhout, D., Stephani, U., Schreiber, S., Eichler, E. E., and Sander, T. (2009) 15q13.3 Microdeletions increase risk of idiopathic generalized epilepsy. Nat. Genet. 41, 160-162.

Hoggart, C. J., Clark, T. G., De Iorio, M. Whittaker, J. C., and Balding, D. J. (2008). Genome-wide significance for dense SNP and resequencing data. Genet. Epidemiol. 32, 179-185.

Howes, O. D., and Kapur, S. (2009). The dopamine hypothesis of schizophrenia: version III - the final common pathway. Schizophr. Bull. 35 549-562.
International HapMap Consortium (2003). The International HapMap Project. Nature 426, 789-796.

International Schizophrenia Consortium (2008). Rare chromosomal deletions and duplications increase risk of schizophrenia. Nature 455, 237-241.

International Schizophrenia Consortium (2009). Common polygenic variation contributes to risk of schizophrenia and bipolar disorder. Nature 460, 748-752.

Jamra, R. A., Schmael, C., Cichon, S. Rietschel, M., Schumacher, J., and Nöthen, M. M. (2006). The G72/G30 gene locus in psychiatric disorders: a challenge to diagnostic boundaries? Schizophr. Bull. 32, 599-608.

Johnson, C., Drgon, T., Liu, Q. R., Walther, D., Edenberg, H., Rice, J., Foroud, T., and Uhl, G. R. (2006). Pooled association genome scanning for alcohol dependence using 104,268 SNPs: validation and use to identify alcoholism vulnerability loci in unrelated individuals from the collaborative study on the genetics of alcoholism. Am. J. Med. Genet. B Neuropsychiatr. Genet. 141B, 844-853.

Jönsson, E. G., Ivo, R., Forslund, K., Mattila-Evenden, M., Rylander, G., Cichon, S., Propping, P., Nöthen M. M., Asberg, M., and Sedvall, G. C. (2001). No association between a promoter dopamine $\mathrm{D}(4)$ receptor gene variant and schizophrenia. Am. J. Med. Genet. 105, 525-528.

Jönsson, E. G., Kaiser, R., Brockmoller, J. Nimgaonkar, V. L., and Crocq, M. A. (2004).Meta-analysis of the dopamine D3 receptor gene (DRD3) Ser9Gly variant and schizophrenia. Psychiatr. Genet. 14, 9-12.

Jönsson, E. G., Sillen,A., Vares, M., Ekholm, B., Terenius, L., and Sedvall, G. C. (2003). Dopamine D2 receptor gene Ser311Cys variant and schizophrenia: association study and meta-analysis. Am. J. Med. Genet. B Neuropsychiatr. Genet. 119B, 28-34.

Karayiorgou, M., Morris, M. A., Morrow, B., Shprintzen, R. J., Goldberg, R., Borrow, J., Gos, A., Nestadt, G., Wolyniec, P. S., Lasseter, V. K., Eisen, H., Childs, B., Kazazian, H. H., Kucherlapati, R., Antonarakis, S. E., Pulver, A. E., and Housman, D. E. (1995). Schizophrenia susceptibility 
associated with interstitial deletions of chromosome 22q11. Proc. Natl. Acad. Sci. U.S.A. 92, 7612-7616.

Kendler, K. S., and Gruenberg, A. M. (1984). An independent analysis of the Danish Adoption Study of Schizophrenia. VI. The relationship between psychiatric disorders as defined by DSM-III in the relatives and adoptees. Arch. Gen. Psychiatry. 41, 555-564.

Kendler, K. S., Gruenberg, A. M., and Kinney, D. K. (1994). Independent diagnoses of adoptees and relatives as defined by DSM-III in the provincial and national samples of the Danish Adoption Study of Schizophrenia. Arch. Gen. Psychiatry 51, 456-468.

Kety, S. S. (1987). The significance of genetic factors in the etiology of schizophrenia: results from the national study of adoptees in Denmark. J. Psychiatr. Res. 21, 423-429.

Kety, S. S., Wender, P. H., Jacobsen, B., Ingraham, L. J., Jansson, L., Faber, B., and Kinney, D. K. (1994). Mental illness in the biological and adoptive relatives of schizophrenic adoptees. Replication of the Copenhagen Study in the rest of Denmark. Arch. Gen. Psychiatry 51, 442-455.

Kirov, G., Grozeva, D., Norton, N., Ivanov, D., Mantripragada, K. K., Holmans, P., Craddock, N., Owen, M. J., and O’Donovan, M. C. (2009a). Support for the involvement of large copy number variants in the pathogenesis of schizophrenia. Hum. Mol. Genet. 18, 1497-1503.

Kirov, G., Zaharieva, I., Georgieva, L., Moskvina, V., Nikolov, I., Cichon, S., Hillmer, A., Toncheva, D., Owen, M. J., and O'Donovan, M. C. (2009b). A genome-wide association study in 574 schizophrenia trios using DNA pooling. Mol. Psychiatry 14, 796-803.

Kirov, G., Gumus, D., Chen, W., Norton, N., Georgieva, L., Sari, M., O’Donovan, M. C., Erdogan, F., Owen, M. J., Ropers, H. H., and Ullmann, R. (2008). Comparative genome hybridization suggests a role for NRXN1 and APBA2 in schizophrenia. Hum. Mol. Genet. 17, 458-465.

Kringlen, E. (2000). Twin studies in schizophrenia with special emphasis on concordance figures. Am. J. Med. Genet. 97, 4-11.

Laursen, T. M., Agerbo, E., and Pedersen, C. B. (2009). Bipolar disorder, schizoaffective disorder, and schizophrenia overlap: a new comorbidity index. J. Clin. Psychiatry 70, 1432-1438.

Lencz, T., Morgan, T. V., Athanasiou, M., Dain, B., Reed, C. R., Kane, J. M., Kucherlapati, R., and Malhotra, A. K. (2007). Converging evidence for a pseudoautosomal cytokine recep- tor gene locus in schizophrenia. Mol. Psychiatry 12, 572-580.

Le-Niculescu, H., Patel, S. D., Bhat, M. Kuczenski, R., Faraone, S. V., Tsuang, M. T., McMahon, F. J., Schork, N. J., Nurnberger, J. I., Jr., and Niculescu, A. B., 3rd. (2009). Convergent functional genomics of genome-wide association data for bipolar disorder: comprehensive identification of candidate genes, pathways and mechanisms. Am. J. Med. Genet. B Neuropsychiatr. Genet. 150B, 155-181.

Lewis, C. M., Levinson, D. F., Wise, L. H., DeLisi, L. E., Straub, R. E., Hovatta, I. Williams, N. M., Schwab, S. G., Pulver, A. E., Faraone, S. V., Brzustowicz, L. M., Kaufmann, C. A., Garver, D. L. Gurling, H. M., Lindholm, E., Coon, H., Moises, H. W., Byerley, W., Shaw, S. H., Mesen, A., Sherrington, R., O'Neill, F.A., Walsh, D., Kendler, K. S., Ekelund, J., Paunio, T., Lonnqvist, J., Peltonen, L., O'Donovan, M. C., Owen, M. J., Wildenauer, D. B., Maier, W., Nestadt, G., Blouin, J. L., Antonarakis, S. E. Mowry, B. J., Silverman, J. M., Crowe, R. R., Cloninger, C. R., Tsuang, M. T., Malaspina, D., Harkavy-Friedman, J. M., Svrakic, D. M., Bassett, A. S., Holcomb, J., Kalsi, G., McQuillin, A., Brynjolfson, J., Sigmundsson, T. Petursson, H., Jazin, E., Zoega, T., and Helgason, T. (2003). Genome scan meta-analysis of schizophrenia and bipolar disorder, part II: Schizophrenia. Am. J. Hum. Genet. 73, 34-48.

Lichtenstein, P., Yip, B. H., Bjork, C., Pawitan, Y., Cannon, T. D., Sullivan, P. F., and Hultman, C. M. (2009) Common genetic determinants of schizophrenia and bipolar disorder in Swedish families: a population-based study. Lancet 373, 234-239.

Liu, Q. R., Drgon, T., Walther, D., Johnson, C., Poleskaya, O., Hess, J., and Uhl, G. R. (2005). Pooled association genome scanning: validation and use to identify addiction vulnerability loci in two samples. Proc. Natl. Acad. Sci. U.S.A. 102, 11864-11869.

Lowing, P. A., Mirsky, A. F., and Pereira, R (1983). The inheritance of schizophrenia spectrum disorders: a reanalysis of the Danish adoptee study data. Am. J. Psychiatry 140, 1167-1171.

Mah, S., Nelson, M. R., Delisi, L. E. Reneland, R. H., Markward, N., James, M. R., Nyholt, D. R., Hayward, N. Handoko, H., Mowry, B., Kammerer, S., and Braun, A.(2006). Identification of the semaphorin receptor PLXNA2 as a candidate for susceptibility to schizophrenia. Mol. Psychiatry 11, 471-478.

Maier, W., Lichtermann, D., Franke, P. Heun, R., Falkai, P., and Rietschel,
M. (2002). The dichotomy of schizophrenia and affective disorders in extended pedigrees. Schizophr. Res. 57, 259-266.

McCarthy, M. I., Abecasis, G. R., Cardon, L. R., Goldstein, D. B., Little, J. Ioannidis, J. P., and Hirschhorn, J. N. (2008). Genome-wide association studies for complex traits: consensus, uncertainty and challenges. Nat. Rev. Genet. 9, 356-369.

Meechan, D. W., Maynard, T. M., Gopalakrishna, D., Wu, Y., and LaMantia, A. S. (2007). When half is not enough: gene expression and dosage in the 22q11 deletion syndrome. Gene Expr. 13, 299-310.

Mefford, H. C., Sharp, A. J., Baker, C., Itsara, A., Jiang, Z., Buysse, K., Huang, S., Maloney, V. K., Crolla, J. A., Baralle, D., Collins, A., Mercer, C., Norga, K. de Ravel, T., Devriendt, K., Bongers, E. M., de Leeuw, N., Reardon, W., Gimelli, S., Bena, F., Hennekam, R. C., Male, A., Gaunt, L., Clayton-Smith, J., Simonic, I., Park, S. M., Mehta, S. G., Nik-Zainal, S., Woods, C. G., Firth, H. V., Parkin, G., Fichera, M., Reitano, S., Lo Giudice, M., Li, K. E., Casuga, I., Broomer, A. Conrad, B., Schwerzmann, M., Raber L., Gallati, S., Striano, P., Coppola, A. Tolmie, J. L., Tobias, E. S., Lilley, C., Armengol, L., Spysschaert, Y., Verloo, P., De Coene, A., Goossens, L., Mortier, G., Speleman, F., van Binsbergen, E., Nelen, M. R., Hochstenbach, R., Poot, M., Gallagher, L., Gill, M., McClellan, J., King, M. C., Regan, R., Skinner, C., Stevenson, R. E., Antonarakis, S. E., Chen, C., Estivill, X., Menten, B. Gimelli, G., Gribble, S., Schwartz, S. Sutcliffe, J. S., Walsh, T., Knight, S. J., Sebat, J., Romano, C., Schwartz, C. E. Veltman,J.A., deVries, B. B., Vermeesch, J. R., Barber, J.C., Willatt, L., Tassabehji, M., and Eichler, E. E. (2008). Recurrent rearrangements of chromosome 1q21.1 and variable pediatric phenotypes. $N$. Engl. J. Med. 359, 1685-1699.

Meyer-Lindenberg, A. S., Olsen, R. K., Kohn, P. D., Brown, T., Egan, M. F., Weinberger, D. R., and Berman, K. F. (2005). Regionally specific disturbance of dorsolateral prefrontal-hippocampal functional connectivity in schizophrenia. Arch. Gen. Psychiatry 62, 379-386.

Miller, D. T., Shen, Y., Weiss, L. A., Korn, J., Anselm, I., Bridgemohan, C., Cox, G. F., Dickinson, H., Gentile, J., Harris, D. J., Hegde, V., Hundley, R., Khwaja, O., Kothare, S., Luedke, C., Nasir, R. Poduri, A., Prasad, K., Raffalli, P. Reinhard, A., Smith, S. E., Sobeih, M. M., Soul, J. S., Stoler, J., Takeoka, M., Tan, W. H., Thakuria, J., Wolff, R. Yusupov, R., Gusella, J. F., Daly, M. J., and Wu, B. L.(2009). Microdeletion/ duplication at 15q13.2q13.3 among individuals with features of autism and other neuropsychiatric disorders. J. Med. Genet. 46, 242-248.

Need, A. C., Ge, D., Weale, M. E., Maia, J., Feng, S., Heinzen, E. L., Shianna, K. V., Yoon, W., Kasperaviciute, D., Gennarelli, M., Strittmatter, W. J., Bonvicini, C., Rossi, G., Jayathilake, K., Cola, P. A., McEvoy, J. P., Keefe, R S., Fisher, E. M., St Jean, P. L., Giegling, I., Hartmann, A. M., Moller, H. J., Ruppert, A., Fraser, G., Crombie, C., Middleton, L. T., St Clair, D., Roses, A. D., Muglia, P., Francks, C., Rujescu, D., Meltzer, H. Y., and Goldstein, D. B (2009). A genome-wide investigation of SNPs and CNVs in schizophrenia. PLoS Genet. 5, e1000373. doi: 10.1371/ journal.pgen.1000373.

Ng, M. Y., Levinson, D. F., Faraone, S. V., Suarez, B. K., DeLisi, L. E., Arinami, T., Riley, B., Paunio, T., Pulver, A. E., Irmansyah, Holmans, P. A., Escamilla, M., Wildenauer, D. B., Williams, N.M., Laurent, C., Mowry, B. J., Brzustowicz, L. M., Maziade, M., Sklar, P., Garver, D. L., Abecasis, G. R., Lerer, B., Fallin, M. D., Gurling, H. M., Gejman, P. V., Lindholm, E., Moises, H. W., Byerley, W., Wijsman, E. M., Forabosco, P. Tsuang, M. T., Hwu, H. G., Okazaki, Y., Kendler, K. S., Wormley, B. Fanous, A., Walsh, D., O'Neill, F. A., Peltonen, L., Nestadt, G., Lasseter, V. K., Liang, K. Y., Papadimitriou, G. M., Dikeos, D. G., Schwab, S. G., Owen, M. J., O’Donovan, M. C., Norton, N., Hare, E., Raventos, H., Nicolini, H., Albus, M., Maier, W., Nimgaonkar, V. L., Terenius, L., Mallet, J., Jay, M., Godard, S., Nertney, D., Alexander, M., Crowe, R. R., Silverman, J. M., Bassett, A. S., Roy, M. A., Merette, C., Pato, C. N., Pato, M. T., Roos, J. L., Kohn, Y., Amann-Zalcenstein, D., Kalsi, G., McQuillin,A., Curtis, D., Brynjolfson, J., Sigmundsson, T., Petursson, H., Sanders, A. R., Duan, J., Jazin, E., Myles-Worsley, M., Karayiorgou, M. and Lewis, C. M. (2009). Meta-analysis of 32 genome-wide linkage studies of schizophrenia. Mol. Psychiatry 14, 774-785.

O’Donovan, M.C., Craddock, N., Norton, N., Williams, H., Peirce, T., Moskvina, V., Nikolov, I., Hamshere, M., Carroll, L., Georgieva, L., Dwyer, S., Holmans, P., Marchini, J. L., Spencer, C. C., Howie, B., Leung, H. T., Hartmann, A. M., Moller, H. J., Morris, D. W., Shi, Y., Feng, G., Hoffmann, P., Propping, P., Vasilescu, C., Maier, W., Rietschel, M., Zammit, S., Schumacher, J. Quinn, E. M., Schulze, T.G., Williams, N. M., Giegling, I., Iwata, N., Ikeda, M., Darvasi, A., Shifman, S., He, L. Duan, J., Sanders, A. R., Levinson, D. 
F., Gejman, P. V., Cichon, S., Nothen, M.M., Gill, M., Corvin,A., Rujescu, D., Kirov, G., Owen, M. J., Buccola, N. G., Mowry, B. J., Freedman, R., Amin, F., Black, D. W., Silverman, J. M., Byerley, W. F., and Cloninger, C. R. (2008). Identification of loci associated with schizophrenia by genome-wide association and follow-up. Nat. Genet. 40, 1053-1055.

Okochi, T., Ikeda, M., Kishi, T., Kawashima, K., Kinoshita, Y., Kitajima, T., Yamanouchi, Y., Tomita, M., Inada, T., Ozaki, N., and Iwata, N. (2009). Meta-analysis of association between genetic variants in COMT and schizophrenia: An update. Schizophr. Res. $110,140-148$.

Owen, M. J., Craddock, N., and Jablensky, A. (2007). The genetic deconstruction of psychosis. Schizophr. Bull. 33, 905-911.

Pe'er, I., Yelensky, R., Altshuler, D., and Daly, M. J. (2008). Estimation of the multiple testing burden for genomewide association studies of nearly all common variants. Genet. Epidemiol. $32,381-385$.

Prasad, K. M., and Keshavan, M.S. (2008). Structural cerebral variations as useful endophenotypes in schizophrenia: do they help construct "extended endophenotypes"? Schizophr. Bull.34, 774-790.

Rietschel, M., Beckmann, L., Strohmaier, J., Georgi, A., Karpushova, A., Schirmbeck, F., Boesshenz, K. V., Schmael, C., Burger, C., Jamra, R. A., Schumacher, J., Hofels, S., Kumsta, R., Entringer, S., Krug, A., Markov, V., Maier, W., Propping, P., Wüst, S., Kircher, T., Nöthen, M. M., Cichon, S., and Schulze, T. G. (2008). G72 and its association with major depression and neuroticism in large populationbased groups from Germany. Am. J. Psychiatry 165, 753-762.

Risch, N., and Merikangas, K. (1996). The future of genetic studies of complex human diseases. Science 273, 1516-1517.

Rujescu, D., Ingason, A., Cichon, S., Pietilainen, O. P., Barnes, M. R., Toulopoulou, T., Picchioni, M., Vassos, E., Ettinger, U., Bramon, E., Murray, R., Ruggeri, M., Tosato, S. Bonetto, C., Steinberg, S., Sigurdsson, E., Sigmundsson, T., Petursson, H. Gylfason, A., Olason, P.I., Hardarsson, G., Jonsdottir, G. A., Gustafsson, O., Fossdal, R., Giegling, I., Moller, H. J., Hartmann, A. M., Hoffmann, P., Crombie, C., Fraser, G., Walker, N., Lonnqvist, J., Suvisaari, J., TuulioHenriksson, A., Djurovic, S., Melle, I. Andreassen, O. A., Hansen, T., Werge, T., Kiemeney, L.A., Franke, B., Veltman, J., Buizer-Voskamp, J. E., Sabatti, C.,
Ophoff, R. A., Rietschel, M., Nothen, M. M., Stefansson, K., Peltonen, L., St Clair, D., Stefansson, H., and Collier, D. A. (2009). Disruption of the neurexin 1 gene is associated with schizophrenia. Hum. Mol. Genet. 18, 988-996.

Schulze, T. G., Ohlraun, S., Czerski, P. M. Schumacher, J., Kassem, L., Deschner, M., Gross, M., Tullius, M., Heidmann, V., Kovalenko, S., Jamra, R. A., Becker, T., Leszczynska-Rodziewicz, A., Hauser, J., Illig, T., Klopp, N. Wellek, S., Cichon, S., Henn, F. A., McMahon, F. J., Maier, W., Propping, P., Nöthen, M. M., and Rietschel, M. (2005). Genotype-phenotype studies in bipolar disorder showing association between the DAOA/G30 locus and persecutory delusions: a first step toward a molecular genetic classification of psychiatric phenotypes. Am. J. Psychiatry 162, 2101-2108.

Schumacher, J., Jamra, R. A., Freudenberg, J., Becker, T., Ohlraun, S., Otte, A. C., Tullius, M., Kovalenko, S., Bogaert, A. V., Maier, W., Rietschel, M., Propping, P., Nöthen, M. M., and Cichon, S. (2004). Examination of G72 and Damino-acid oxidase as genetic risk factors for schizophrenia and bipolar affective disorder. Mol. Psychiatry 9 , 203-207.

Serretti, A., Lorenzi, C., Mandelli, L., Cichon, S., Schumacher, J., Nöthen, M. M., Rietschel, M., Tullius, M., and Ohlraun, S. (2004). DRD4 exon 3 variants are not associated with symptomatology of major psychoses in a German population. Neurosci. Lett. 368, 269-273.

Shi, J., Gershon, E. S., and Liu, C. (2008) Genetic associations with schizophrenia: meta-analyses of 12 candidate genes. Schizophr. Res. 104, 96-107.

Shi, J., Levinson, D. F., Duan, J., Sanders, A. R., Zheng, Y., Pe'er, I., Dudbridge, F., Holmans, P. A., Whittemore, A. S., Mowry, B. J., Olincy, A., Amin, F., Cloninger, C. R., Silverman, J. M., Buccola, N. G., Byerley, W. F., Black, D. W., Crowe, R. R., Oksenberg, J. R., Mirel, D. B., Kendler, K. S., Freedman, R., and Gejman, P. V. (2009). Common variants on chromosome $6 \mathrm{p} 22.1$ are associated with schizophrenia. Nature 460, 753-757.

Shifman, S., Bronstein, M., Sternfeld, M. Pisante-Shalom, A., Lev-Lehman, E., Weizman, A., Reznik, I., Spivak, B., Grisaru, N., Karp, L., Schiffer, R., Kotler, M., Strous, R. D., SwartzVanetik, M., Knobler, H. Y., Shinar, E., Beckmann, J. S., Yakir, B., Risch, N., Zak, N. B., and Darvasi, A. (2002). A highly significant association between a COMT haplotype and schizophrenia. Am. J. Hum. Genet. 71, 1296-1302.
Shifman, S., Johannesson, M., Bronstein, M., Chen, S. X., Collier, D. A., Craddock, N. J., Kendler, K. S., Li, T., O’Donovan, M., O’Neill, F. A., Owen, M.J., Walsh, D., Weinberger, D. R., Sun, C., Flint, J., and Darvasi, A. (2008). Genome-wide association identifies a common variant in the reelin gene that increases the risk of schizophrenia only in women. PLoS Genet. 4, e28. doi: 10.1371/journal.pgen.0040028.

Sivagnanasundaram, S., Fletcher, D. Hubank, M., Illingworth, E., Skuse, D. and Scambler, P. (2007). Differential gene expression in the hippocampus of the Df1/+ mice: a model for 22q11.2 deletion syndrome and schizophrenia. Brain Res. 1139, 48-59.

Sivagnanasundaram, S., Morris, A. G. Gaitonde, E.J., McKenna, P. J., Mollon, J. D., and Hunt, D. M. (2000). A cluster of single nucleotide polymorphisms in the $5^{\prime}$-leader of the human dopamine D3 receptor gene (DRD3) and its relationship to schizophrenia. Neurosci. Lett. 279, 13-16.

Staddon, S., Arranz, M. J., Mancama, D., Perez-Nievas, F., Arrizabalaga I., Anney, R., Buckland, P., Elkin, A. Osborne, S., Munro, J., Mata, I., and Kerwin, R. W. (2005). Association between dopamine D3 receptor gene polymorphisms and schizophrenia in an isolate population. Schizophr. Res. $73,49-54$

Stefansson, H., Ophoff, R. A., Steinberg, S. Andreassen, O.A., Cichon, S., Rujescu, D., Werge, T., Pietilainen, O. P., Mors, O., Mortensen, P. B., Sigurdsson, E. Gustafsson, O., Nyegaard, M., TuulioHenriksson, A., Ingason, A., Hansen, T., Suvisaari, J., Lonnqvist, J., Paunio, T., Borglum, A.D., Hartmann, A., FinkJensen, A., Nordentoft, M., Hougaard D., Norgaard-Pedersen, B., Bottcher, Y., Olesen, J., Breuer, R., Moller, H. J. Giegling, I., Rasmussen, H. B., Timm, S., Mattheisen, M., Bitter, I., Rethelyi, J. M., Magnusdottir, B. B., Sigmundsson, T., Olason, P., Masson, G., Gulcher J. R., Haraldsson, M., Fossdal, R. Thorgeirsson, T. E., Thorsteinsdottir, U., Ruggeri, M., Tosato, S., Franke, B., Strengman, E., Kiemeney, L. A. Melle, I., Djurovic, S., Abramova L., Kaleda, V., Sanjuan, J., de Frutos, R., Bramon, E., Vassos, E., Fraser, G. Ettinger, U., Picchioni, M., Walker, N., Toulopoulou, T., Need, A. C., Ge, D. Yoon, J. L., Shianna, K. V., Freimer, N. B., Cantor, R. M., Murray, R., Kong, A., Golimbet, V., Carracedo, A., Arango, C., Costas, J., Jonsson, E. G., Terenius, L., Agartz, I., Petursson, H., Nothen, M. M., Rietschel, M., Matthews, P. M., Muglia, P., Peltonen, L., St Clair D., Goldstein, D. B., Stefansson, K., and Collier, D. A. (2009). Common variants conferring risk of schizophrenia. Nature 460, 744-747.

Stephan, K. E., Baldeweg, T., and Friston, K. J. (2006). Synaptic plasticity and dysconnection in schizophrenia. Biol. Psychiatry 59, 929-939.

Sullivan, P.F., Kendler, K. S., and Neale, M. C. (2003). Schizophrenia as a complex trait: evidence from a meta-analysis of twin studies. Arch. Gen. Psychiatry 60, 1187-1192.

Sullivan, P. F., Lin, D., Tzeng, J. Y., van den Oord, E., Perkins, D., Stroup, T. S., Wagner, M., Lee, S., Wright, F. A., Zou, F., Liu, W., Downing, A. M., Lieberman, J., and Close, S. L. (2008). Genomewide association for schizophrenia in the CATIE study: results of stage 1. Mol. Psychiatry 13, 570-584.

Talkowski, M. E., Kirov, G., Bamne, M., Georgieva, L., Torres, G., Mansour, H. Chowdari, K. V., Milanova, V., Wood, J., McClain, L., Prasad, K., Shirts, B., Zhang, J., O'Donovan, M. C., Owen, M. J., Devlin, B., and Nimgaonkar, V. L. (2008). A network of dopaminergic gene variations implicated as risk factors for schizophrenia. Hum. Mol. Genet. 17, 747-758.

Tienari, P., Wynne, L. C., Laksy, K. Moring, J., Nieminen, P., Sorri, A., Lahti, I., and Wahlberg, K. E. (2003). Genetic boundaries of the schizophrenia spectrum: evidence from the Finnish Adoptive Family Study of Schizophrenia. Am. J. Psychiatry 160, 1587-1594

Tienari, P., Wynne, L. C., Moring, J., Laksy, K., Nieminen, P., Sorri, A., Lahti, I., Wahlberg, K. E., Naarala, M., KurkiSuonio, K., Saarento, O., Koistinen, P., Tarvainen, T., Hakko, H., and Miettunen, J. (2000). Finnish adoptive family study: sample selection and adoptee DSM-III-R diagnoses. Acta Psychiatr. Scand. 101, 433-443.

Treutlein, J., Cichon, S., Ridinger, M., Wodarz, N., Soyka, M., Zill, P., Maier, W., Moessner, R., Gaebel, W., Dahmen, N., Fehr, C., Scherbaum, N., Steffens, M., Ludwig, K. U., Frank, J., Wichmann, H. E., Schreiber, S., Dragano, N., Sommer, W. H., Leonardi-Essmann, F., Lourdusamy, A., Gebicke-Haerter, P., Wienker, T. F., Sullivan, P. F., Nöthen, M.M., Kiefer, F., Spanagel, R., Mann, K., and Rietschel, M. (2009). Genome-wide association study of alcohol dependence. Arch Gen. Psychiatry 66, 773-784.

Valles, V., Van Os, J., Guillamat, R. Gutierrez, B., Campillo, M., Gento, P., and Fananas, L. (2000). Increased morbid risk for schizophrenia in families of in-patients with bipolar illness. Schizophr. Res. 42, 83-90.

Van Snellenberg, J. X., and de Candia, T. (2009). Meta-analytic evidence for 
familial coaggregation of schizophrenia and bipolar disorder. Arch. Gen. Psychiatry 66, 748-755.

Vrijenhoek, T., Buizer-Voskamp, J. E., van der Stelt, I., Strengman, E., Sabatti, C., Geurts van Kessel, A., Brunner, H. G., Ophoff, R. A., and Veltman, J. A. (2008). Recurrent CNVs disrupt three candidate genes in schizophrenia patients. Am. J. Hum. Genet. 83, 504-510.

Walsh, T., McClellan, J. M., McCarthy, S. E., Addington, A. M., Pierce, S. B., Cooper, G. M., Nord, A. S., Kusenda, M., Malhotra, D., Bhandari, A., Stray, S. M., Rippey, C. F., Roccanova, P., Makarov, V., Lakshmi, B., Findling, R. L., Sikich, L., Stromberg, T., Merriman, B., Gogtay, N., Butler, P., Eckstrand, K., Noory, L., Gochman, P., Long, R.,
Chen, Z., Davis, S., Baker, C., Eichler, E. E., Meltzer, P. S., Nelson, S. F., Singleton, A. B., Lee, M. K., Rapoport, J. L., King, M. C., and Sebat, J. (2008). Rare structural variants disrupt multiple genes in neurodevelopmental pathways in schizophrenia. Science 320, 539-543.

Wickham, H., Walsh, C., Asherson, P., Gill, M., Owen, M. J., McGuffin, P., Murray, R., and Sham, P. (2002). Familiality of clinical characteristics in schizophrenia. J. Psychiatr. Res. 36, 325-329.

Wickham, H., Walsh, C., Asherson, P., Taylor, C., Sigmundson, T., Gill, M., Owen, M. J., McGuffin, P., Murray, R., and Sham, P. (2001). Familiality of symptom dimensions in schizophrenia. Schizophr. Res. 47, 223-232.
Wynne, L. C., Tienari, P., Nieminen, P., Sorri, A., Lahti, I., Moring, J., Naarala, M., Laksy, K., Wahlberg, K. E., and Miettunen, J. (2006). I. Genotypeenvironment interaction in the schizophrenia spectrum: genetic liability and global family ratings in the Finnish Adoption Study. Fam Process. 45, 419-434.

Xu, B., Roos, J. L., Levy, S., van Rensburg, E. J., Gogos, J. A., and Karayiorgou, M. (2008). Strong association of de novo copy number mutations with sporadic schizophrenia. Nat. Genet. 40, 880-885.

Conflict of Interest Statement: The authors declare that the research was conducted in the absence of any commercial or financial relationships that could be construed as a potential conflict of interest.

Received:28 August 2009; paper pending published: 19March 2010; accepted: 19April 2010; published online: 11 May 2010.

Citation: Nieratschker V, Nöthen MM and Rietschel M (2010) New genetic findings in schizophrenia: is there still room for the dopamine hypothesis of schizophrenia? Front. Behav. Neurosci. 4:23. doi: 10.3389/fnbeh.2010.00023

Copyright (c) 2010 Nieratschker, Nöthen and Rietschel. This is an open-access article subject to an exclusive license agreement between the authors and the Frontiers Research Foundation, which permits unrestricted use, distribution, and reproduction in any medium, provided the original authors and source are credited. 